Louisiana State University

LSU Digital Commons

Faculty Publications

Department of Biological Sciences

6-14-2011

\title{
The gp130 receptor cytokine family: Regulators of adipocyte development and function
}

Ursula A. White

Louisiana State University

Jacqueline M. Stephens

Louisiana State University

Follow this and additional works at: https://digitalcommons.Isu.edu/biosci_pubs

\section{Recommended Citation}

White, U., \& Stephens, J. (2011). The gp130 receptor cytokine family: Regulators of adipocyte development and function. Current Pharmaceutical Design, 17(4), 340-346. https://doi.org/10.2174/ 138161211795164202

This Article is brought to you for free and open access by the Department of Biological Sciences at LSU Digital Commons. It has been accepted for inclusion in Faculty Publications by an authorized administrator of LSU Digital Commons. For more information, please contact ir@lsu.edu. 


\title{
The gp130 Receptor Cytokine Family: Regulators of Adipocyte Development and Function
}

\author{
Ursula A. White and Jacqueline M. Stephens* \\ Department of Biological Sciences, Louisiana State University, Baton Rouge, LA 70803
}

\section{Abstract}

Gp130 cytokines are involved in the regulation of numerous biological processes, including hematopoiesis, immune response, inflammation, cardiovascular action, and neuronal survival. These cytokines share glycoprotein 130 as a common signal transducer in their receptor complex and typically activate STAT3. Most gp130 cytokines have paracrine or endocrine actions, and their levels can be measured in circulation in rodents and humans. In recent years, various laboratories have conducted studies to demonstrate that gp130 cytokines can modulate adipocyte development and function. Therefore, these studies suggest that some gp130 cytokines may be viable anti-obesity therapeutics. In this review, we will summarize the reported effects of gp130 cytokines on adipocyte differentiation and adipocyte function. In addition, the modulation of gp130 cytokines in conditions of obesity, insulin resistance, and Type 2 diabetes will be presented.

\section{INTRODUCTION}

The Interleukin (IL)-6 family of cytokines is a group of functionally and structurally related proteins that includes Interleukin-6 (IL-6), Interleukin-11 (IL-11), Interleukin-27 (IL-27), leukemia inhibitory factor (LIF), oncostatin M (OSM), ciliary neurotrophic factor (CNTF), cardiotrophin-1 (CT-1), novel neurotrophin-1/B cell stimulating factor-3 or cardiotrophinlike cytokine (CLC), and neuropoietin (NP) (reviewed in [1]). These cytokines regulate a variety of complex biological processes, including hematopoiesis, immune response, inflammation, proliferation, differentiation, mammalian reproduction, cardiovascular action, and neuronal survival [reviewed in [2]). Activation of all cytokines in the IL-6 family involves signaling via the Janus Kinase/Signal Transducer and Activator of Transcription (JAK/STAT) pathway. Typically STAT3 is activated and, to a lesser extent, STAT1 (reviewed in [2]). The IL-6 cytokine family can also activate other signaling pathways, including the MAPK (mitogen-activated protein kinase) cascade, PI3K (phosphatidylinositol-3 kinase), mTOR (mammalian target of rapamycin/p70 S6 kinase), and AMPK (5' adenosine monophosphate-activated protein kinase) (reviewed in [3]).

The IL- 6 family is commonly referred to as gp 130 cytokines because all members of this family utilize glycoprotein 130 as a common signal transducer within their receptor complex that is required for signaling (reviewed in [4]). Though originally characterized as having unique properties, gp130 cytokines are known to function in a pleiotropic and redundant manner. The shared usage of signal transducers in the receptor complexes likely accounts for the functional redundancy of gp130 cytokines in mediating biological effects. The ubiquitous expression of gp130 facilitates the pleiotropic nature of these cytokines. The differences in gp130 cytokine activity can be partially attributed to the use of additional

*Address correspondence to this author at the Louisiana State University, Department of Biological Sciences, 202 Life Sciences Bldg, Baton Rouge, LA 70803; Tel: (225)-578-1749; Fax: (225)-578-2597; jsteph1@1su.edu. 
receptor components that are utilized by each family member, including the LIF receptor and the cytokine's specific $\alpha$ receptor. IL- 6 and IL-11 initially bind to the IL-6 receptor $\alpha$ [5] and IL-11 receptor $\alpha$ [6], respectively, and then the complex associates with a gp130 homodimer complex for signaling. IL-27 engages a gp130/WSX-1 heterodimeric receptor complex [7]. LIF and CT-1 require the gp130/LIF receptor (LIFR) complex to mediate signal transduction $[8,9]$. CT-1 has been reported to recruit an alpha receptor [10], which to date has not been characterized. OSM has been reported to utilize the gp130/LIFR complex [11], and can alternatively utilize a gp130/OSM receptor (OSMR) complex [12]. However, recent studies largely indicate that OSM primarily signals via the OSMR and not the LIFR. Both CNTF and CLC utilize a signaling complex, including CNTFR $\alpha$, gp130, and LIFR for signal transduction [13; 14]. NP was also reported to utilize this tri-partite receptor complex [15]; however, recent studies from our laboratory demonstrate that NP induced STAT3 activation is not mediated by LIFR signaling [16]. The receptor components for each gp130 cytokine are reviewed in Table 1.

In recent years, gp130 cytokines have become a focus of attention in the scientific community, as they have been implicated as potential therapeutic targets in obesity (reviewed in [3]). It is well documented that obesity is a risk factor for a variety of other metabolic abnormalities, including Type 2 Diabetes Mellitus (T2DM). Therefore, the study of adipose tissue, particularly the adipocyte, is central to understanding the pathogenesis of obesity and related disorders. Numerous findings in the last decade have highlighted the differential effects of gp130 cytokines on important adipocyte functions. Our studies and others have shown that adipocytes in vitro and adipose tissue in vivo are responsive to gp130 cytokines [17-24] and exert differential effects on adipogenesis [22-30] and insulin action [20-24; 27]. The mechanisms and complex interactions underlying gp130 cytokine action in adipose tissue have not been fully elucidated. Further analyses are necessary to provide insight to the diverse roles of the gp130 family and to understand their contribution to metabolic disease states.

\section{INTERLEUKIN-6}

Interleukin-6 (IL-6) is a pleiotropic cytokine that regulates various physiological processes in multiple tissues, including inflammation, hematopoiesis, immune responses, and host defense mechanisms (reviewed in [31]). Because an estimated one-third of the total basal IL-6 concentration in healthy humans is estimated to originate from adipose tissue [32], IL-6 is considered an adipokine. Adipocytes produce and secrete only a fraction of adipose tissue IL-6 [33], and it is well established that other cell types in adipose tissue are capable of IL-6 production [34; 35]. In the last decade, IL-6 has been intensely investigated and implicated as a major player in the regulation of metabolic disease states.

Data regarding the role of IL-6 in both obesity and insulin resistance are controversial and unresolved (reviewed in [36-38]). Though characterized as both a pro- and antiinflammatory cytokine, IL-6 is well recognized as a mediator of the low-grade chronic inflammatory state of obesity (reviewed in [31]). Numerous studies have shown that IL-6 levels are greatly elevated in obese humans and strongly correlated with increased body mass index (BMI) and waist circumference [39-42]. IL-6 has been implicated as a marker for visceral adipose tissue $[43 ; 44]$ because visceral adipose tissue releases more IL-6 than subcutaneous adipose tissue [33; 35]. Conversely, one of the most striking observations highlighting the anti-obesogenic effects of IL-6 was that knockout mice (IL-6-/-) developed mature onset obesity, hypertriglyceridemia, and glucose intolerance [45]. However, this phenotype was not observed in other studies where IL- 6 deficient mice did not develop age-related obesity or metabolic syndrome [46]. Overall, the fact that IL-6 is released from adipose tissue into systemic circulation and can positively correlate with 
obesity and percent body fat implicates a possible role for IL-6 in regulating body weight and lipid metabolism.

Increasing data suggest that elevated plasma IL-6 is also associated with obesity-related insulin resistance. The most recent human studies demonstrate that increased IL-6 levels correlate with obesity (BMI) and are not necessarily associated with the Type 2 diabetic state [47]. Yet, another study indicates IL-6 levels are higher in subjects with obesity-related insulin resistance [48]. Other findings indicate that increased IL-6 concentrations are related to adiposity and fat mass but not to insulin action or responsiveness [49; 50]. Hence, high circulating levels of IL-6 may not be present in non-obese T2DM patients, and these studies suggest that the relationship between IL-6 and insulin resistance seems to be mediated through obesity. However, there are a number of studies both in vitro and in vivo that demonstrate that IL-6 is capable of inducing insulin resistance. Though many of the in vivo insulin resistant properties of IL- 6 are characterized in the rodent liver [51-56], IL-6 can also induce insulin resistance in cultured murine adipocytes by inhibiting glucose uptake and impairing insulin signaling and action [20; 21]. Whether or not IL-6 impairs insulin action in adipose tissue in vivo has yet to be clearly determined. The notion that IL-6 induces insulin resistance is challenged by several findings demonstrating the production [57] and release [58; 59] of IL-6 from contracting human skeletal muscle cells due to physical exercise, a known insulin sensitizer [60; 61]. Overall, persistent secretion and circulation of IL-6 in states of chronic inflammation, such as obesity, may promote insulin resistance. Hence, IL-6 plasma concentrations combined with other factors may be used as a predictor for the development of T2DM [62-64].

Evidence is emerging that IL-6 can directly affect lipid metabolism and activate pathways to promote increased energy turnover. Several reports indicate lipolytic properties of IL-6. IL-6 has been shown to stimulate lipolysis in humans, also increasing free fatty acid concentrations and whole body fat oxidation [65-67]. In addition, IL-6 increases lipolysis and significantly lowers adipose tissue lipoprotein lipase (LPL) activity in both cultured adipocytes in vitro and mice in vivo [68-70]. Despite discrepancies regarding the effects of IL-6, it can be inferred that overabundance of adipose tissue-derived IL-6 has significant effects on body weight and lipid metabolism. Several findings have shown that IL-6 can also affect other adipokines. Notably, IL-6 can decrease the expression and secretion of adiponectin in human adipocytes, as well as other markers of adipocyte differentiation [30; $71 ; 72]$. Overall, IL-6 may play a pivotal role in metabolic diseases, including obesity. Therefore, understanding and clarifying its role in the regulation of metabolism has merit.

\section{CILIARY NEUROTROPHIC FACTOR}

Ciliary neurotrophic factor (CNTF) is a neurocytokine expressed by glial cells in peripheral nerves and in the central nervous system that was originally identified for its role in the differentiation and survival of neuronal cell types (reviewed in [73]). During a clinical trial evaluating the effects of CNTF on progression of the neurodegenerative disease amyotrophic lateral sclerosis, researchers discovered that CNTF treated patients underwent marked weight loss [74]. Since this discovery, CNTF has been intensely investigated to characterize its anti-obesigenic properties.

CNTF treatment of mice reduces adiposity and body weight and improves diabetic parameters in both genetic and diet-induced models of obesity/T2DM [75-77]. Hence, CNTF provided a cytokine-mediated anti-obesity effect that could act independently of leptin and circumvent leptin-resistance. Due to these profound effects, a human recombinant variant of CNTF, Axokine, was engineered and administered to patients in a series of clinical trials. Axokine was shown to induce weight loss in human subjects [78], as well as 
rodent models of obesity [79]. Importantly, Axokine decreased food intake, increased energy expenditure, and caused a sustained reduction in body weight. The beneficial effects of human recombinant CNTF in obese/T2DM rodents included a reduction in white adipose tissue fat mass, body weight, blood glucose, serum free fatty acids, and pancreatic islet triacylglycerides, as well as enhanced expression of genes associated with energy metabolism in brown adipose tissue [80]. CNTF was recognized as a therapeutic target for obesity and the focus of extensive research to elucidate its potential effects on metabolic pathways and mechanisms of action.

In addition to direct effects of CNTF on the CNS, studies have shown that CNTF may directly act on cells from peripheral tissues to modulate lipid and energy metabolism via a centrally-independent manner. In mouse brown adipocytes, CNTF directly activates several important metabolic signaling proteins and pathways including STAT3, MAPK, Akt, and p70 S6 kinase [81]. Functionally, CNTF enhanced the induction of uncoupling-protein 1, providing evidence for a peripheral role in regulating energy homeostasis. In addition, CNTF activates STAT3 in both cultured adipocytes in vitro and white adipose tissue in vivo in rodents [22]. Importantly, CNTF treatment conferred insulin sensitivity in cultured murine adipocytes and resulted in increased glucose transporter-4 (GLUT4) and insulin receptor substrate-1 (IRS-1) expression and activation [22]. In addition, CNTF receptor expression was substantially induced in fat pads of numerous rodent models of obesity/ T2DM [22], which may suggest a compensatory role for this cytokine to enhance insulin sensitivity. The first evidence to strongly suggest that CNTF could act in a centrally independent manner showed that intraperitoneally (IP), but not intracerebroventricularly (ICV), delivered CNTF induced various metabolic signaling pathways, as well as promoted insulin sensitivity and fatty acid oxidation via an AMP-activated protein kinase (AMPK)dependent mechanism in skeletal muscle of mice fed a high fat diet [82]. Additional findings highlight the cellular and molecular mechanisms by which CNTF causes fat loss. Recent studies have shown that CNTF-mediated reductions in adipose tissue mass in rats resulted from decreased adipocyte area and triglyceride content and enhanced fatty acid oxidation [83]. Other studies indicate that CNTF reduced adipose tissue mass in rats via apoptosis [84]. Acute and chronic treatments of CNTF inhibit leptin expression and secretion [85], indicating that CNTF can modulate adipocyte endocrine function. Overall, CNTF acts both centrally as well as peripherally to promote weight reduction, insulin sensitivity, and fatty acid oxidation. Further analyses are required to better understand its potential as a therapeutic for obesity and Type 2 diabetes.

\section{LEUKEMIA INHIBITORY FACTOR}

Leukemia inhibitory factor (LIF) is one of the most studied gp130 cytokines and was originally indentified for its ability to inhibit the growth of a leukemic cell line. The most widely recognized function of LIF is its ability to maintain the totipotency of embryonic stem cells [86]. However, LIF exerts a wide variety of pleitropic actions, including acting as a stimulus for platelet formation, modulating proliferation of a variety of cell types, enhancing survival of peripheral neurons, promoting bone formation, and enhancing acute phase production by hepatocytes. Both adipocytes in vitro and adipose tissue in vivo are responsive to LIF [19]. Interestingly, LIF was characterized as an inducer of cachetic weight loss in mice engrafted with a melanoma cell line that overproduces LIF [87]. However, it was not investigated whether these weight loss effects were mediated by direct effects of LIF on adipocytes. Subsequently, LIF was found to inhibit lipoprotein lipase (LPL) expression and activity in 3T3-L1 and 3T3-F442A murine adipocytes, without affecting the rate of lipogenesis [88]. Proadipogenic effects of LIF have been shown by enhanced activity of glycerol-phosphate dehydrogenase and accumulation of lipid in Ob1771 cells during adipogenesis [89]. However, other findings have shown that LIF prevents adipogenesis in 
bone marrow stromal cells [90]. In 3T3-L1 cells, studies indicate that, unlike other gp130 cytokines, LIF does not modulate adipogenesis [24; 27]. Collectively, these studies suggest that the effects of LIF on adipogenesis vary with the developmental stage of the cells or tissue. To date, there have been very few studies on the effects of LIF in mature adipocytes in vitro or on adipose tissue in vivo. In murine adipocytes, chronic LIF treatment does not induce insulin resistance but decreases the expression of sterol regulatory element binding protein (SREBP-1) and the levels of stored triacylglycerides [27]. In summary, the studies of LIF in adipose tissue suggest adipogenesis can be modulated by this gp 130 cytokine at certain stages of development and can control the expression of genes associated with lipid metabolism.

\section{ONCOSTATIN M}

Oncostatin M (OSM) shares two primary similarities with LIF. First, human oncostatin was identified for its ability to inhibit the growth of cancer lines [91]. Second, OSM shares substantial sequence identity with LIF [92]. Like other gp130 cytokines, OSM can modulate a variety of biological processes and has some functional overlap with LIF. It has been suggested that OSM and LIF evolved by gene duplication relatively recently [93]. Unlike CT-1 and some other gp130 cytokines, OSM has its own specific receptor that heterodimerizes with gp130 [94]. The oncostatin receptor, OSMR $\beta$, appears to mediate the majority of the effects of OSM. Murine adipocytes in vitro and white adipose tissue in vivo are responsive to OSM and recent studies have shown that OSM can inhibit preadipocyte differentiation [24; 25]. In mature fat cells, OSM has been shown to inhibit adiponectin expression [95]. Overall, these studies indicate that OSM has negative effects on fat cells since it enhances two conditions, inhibition of adipogenesis and reduced adiponectin expression, which are associated with metabolically unfavorable events in adipocytes and in the whole organism.

\section{CARDIOTROPHIN-1}

Cardiotrophin-1 (CT-1) is a gp130 cytokine family member that was identified in 1995 in a cDNA library derived from mouse embryoid bodies and was shown to support in vitro cardiomyocyte survival and hypertrophy [96]. CT-1 is a 200 amino acid protein with a molecular mass of approximately $21.5 \mathrm{kD}$ [96]. CT-1 mRNA expression has been detected at high levels in the heart, skeletal muscle, and liver, as well as in fetal heart, lung, and kidney. Lower amounts have also been detected in a variety of other tissues [96]. Both functional and receptor binding studies in cultured cardiomyocytes have shown that CT-1 signals through the gp130/LIFR heterodimer without the further requirement for an -subunit [9; 97]. The majority of studies on CT-1 indicate a role of this gp130 cytokine in a variety of heart pathologies, including hypertension, myocardial infarction, ischemia, and cardiomyopathy (reviewed in [98]). Circulating CT-1 levels are readily measured in both rodents and humans [99-101]. Although rodent adipocytes and adipose tissue are highly responsive to CT-1 [23; 102], the effects of CT-1 on adipocytes have not been widely studied. In vitro studies indicate that CT-1 does not inhibit preadipocyte differentiation, but does induce insulin resistance in mature murine fat cells [23]. Of note, one recent study suggests that CT-1 is produced in adipose tissue [103]. Overall, these observations suggest that CT-1 may be a novel and potentially important link between obesity/T2DM and cardiovascular disease.

\section{NEUROPOIETIN}

Neuropoeitin (NP) was characterized as a potential regulator of murine central nervous system development, with the ability to modulate motor neuron survival in vitro [15]. NP was shown to be highly expressed in mouse embryonic neuroepithelia [15] and can induce 
neuroepithelial cells to differentiate into astrocytes [104]. Though the analysis of NP action has been limited to the nervous system, studies from our laboratory have also partially elucidated the effects and differential roles of NP in murine adipocytes [24]. Our data indicate that NP is a potent activator of STAT3 and MAPK (ERKs 1 and 2) in both 3T3-L1 adipocytes in vitro and adipose tissue in vivo. Importantly, this cytokine was shown to affect essential fat cell functions in rodents, such as inhibiting adipocyte differentiation and attenuating insulin-stimulated glucose uptake and insulin signaling both in vitro and in vivo [24]. Continued investigation of NP may reveal additional functions in adipose tissue that have significant metabolic effects.

\section{INTERLEUKIN-11}

Interleukin-11 (IL-11) is a bone marrow stromal-derived growth factor that was originally characterized for its role in hematopoiesis [105]. Subsequent analyses revealed that IL-11 could inhibit adipogenesis of 3T3-L1 preadipocytes and suppress lipoprotein lipase activity in fully differentiated murine adipocytes [106; 107]. Several additional studies document the ability of IL-11 to inhibit adipocyte differentiation, as well as the expression of adipogenic markers $[28 ; 29 ; 108 ; 109]$. IL-11 has been shown to activate various proteins and signaling pathways in 3T3-L1 cells, such as STATs 1 and 3, MAPK (ERK), p70 S6 protein kinase, and phosphatidylinositol 3-kinase (PI3-kinase) [18; 110; 111]. The anti-inflammatory effects of IL-11 are demonstrated by prevention of streptozotocin-induced diabetes in mice, as well as the inhibition of inflammatory pathways, specifically nuclear factor kappa- beta (NFאB), in islets [112]. Additional studies may reveal multiple roles for IL-11 in adipose tissue, such as regulating the production of secreted inflammatory cytokines that mediate insulin resistance.

\section{OTHER GP130 CYTOKINES}

Cardiotrophin-like cytokine (CLC) was identified as a neurotrophic factor that has B cell stimulating effects, promotes survival of neuronal cells, and modulates corticotroph cell function [113; 114]. Though highly expressed in the spleen and lymph nodes, CLC is also expressed in a variety of other tissues, which suggests important biological roles in cellular functions (reviewed in [115]). Interleukin- 27 (IL-27) was discovered to be important in processes such as neuronal growth, bone maintenance, cardiac development, and immune response regulation (reviewed in [116]). Numerous reports suggest a pleiotrophic nature for this gp130 cytokine, for IL-27 is associated with both pro- and anti-inflammatory processes. To date, the effects of CLC and IL-27 in adipose tissue have not been characterized, yet serum IL-27 levels can be measured [122].

\section{CONCLUSIONS}

Though the functions and mechanisms underlying the actions of gp130 cytokines in adipose tissue have not been fully elucidated, circulating levels of many gp130 cytokines in humans have been examined and shown to have divergent effects [47-49; 103; 117-122]. In addition, many gp130 cytokines activate common signaling pathways, including JAK/STAT and MAPK (ERK), and utilize the same receptor components in adipocytes in vitro and adipose tissue in vivo. Analysis of gp130 signaling also revealed that gp130 cytokines have the unique ability to crosstalk with other members of the gp130 family to attenuate one another's signaling, and this crosstalk is correlated with the degradation of the LIFR via a lysosome-mediated pathway [102]. Additional studies from our laboratory provide evidence for this inhibitory crosstalk in white adipose tissue in vivo (unpublished). The fact that gp130 cytokines not only activate signaling pathways in vivo, but also inhibit subsequent signaling of other gp130 family members confirms that a detailed analysis of crosstalk 
mechanisms and interactions is relevant for a more detailed perspective of gp130 cytokine secretion and action.

Further studies are needed to examine how gp130 cytokines could possibly contribute to or affect metabolic disease states that are characterized by the expression of multiple cytokines, including those belonging to the gp130 family. Adipose tissue is comprised of various cell types. Recent studies have shown the presence of a variety of immune cells (macrophages, $\mathrm{T}$ cells) that are present in adipose tissue and regulated by pathological conditions (obesity, insulin resistance, Type 2 diabetes). The production of gp130 cytokines from these immune cells is an unexplored area of inflammation and metabolic diseases. Nonetheless, as described above and summarized in Tables 2 and 3, several gp130 cytokines have profound effects on adipocyte differentiation and insulin sensitivity in mature fat cells. The differential response of adipocytes to gp130 cytokines cannot be explained by their receptor components, suggesting that other proteins must play a role in mediating the specificity of these cytokines. A greater understanding of the diverse actions of gp130 cytokines in adipose tissue is important and will be essential in understanding the functions and sources of these cytokines and may also provide valuable information in the potential development of novel therapeutic strategies.

\section{REFERENCES}

[1]. Fasnacht N, Muller W. Conditional gp130 deficient mouse mutants. Semin Cell Dev Biol. 2008; 19(4):379-84. [PubMed: 18687405]

[2]. Heinrich PC, Behrmann I, Haan S, Hermanns HM, Muller-Newen G, Schaper F. Principles of interleukin (IL)-6-type cytokine signalling and its regulation. Biochem J. 2003; 374(Pt 1):1-20. [PubMed: 12773095]

[3]. Febbraio MA. gp130 receptor ligands as potential therapeutic targets for obesity. J Clin Invest. 2007; 117(4):841-9. [PubMed: 17404609]

[4]. Taga T, Kishimoto T. Gp130 and the interleukin-6 family of cytokines. Annu Rev Immunol. 1997; 15:797-819. [PubMed: 9143707]

[5]. Taga T, Hibi M, Hirata Y, et al. Interleukin-6 triggers the association of its receptor with a possible signal transducer, gp130. Cell. 1989; 58(3):573-81. [PubMed: 2788034]

[6]. Hilton DJ, Hilton AA, Raicevic A, et al. Cloning of a murine IL-11 receptor alpha-chain; requirement for gp130 for high affinity binding and signal transduction. EMBO J. 1994; 13(20): 4765-75. [PubMed: 7957045]

[7]. Pflanz S, Hibbert L, Mattson J, et al. WSX-1 and glycoprotein 130 constitute a signal-transducing receptor for IL-27. J Immunol. 2004; 172(4):2225-31. [PubMed: 14764690]

[8]. Gearing DP, Thut CJ, VandeBos T, et al. Leukemia inhibitory factor receptor is structurally related to the IL-6 signal transducer, gp130. EMBO J. 1991; 10(10):2839-48. [PubMed: 1915266]

[9]. Pennica D, Shaw KJ, Swanson TA, et al. Cardiotrophin-1. Biological activities and binding to the leukemia inhibitory factor receptor/gp130 signaling complex. J Biol Chem. 1995; 270(18): 10915-22. [PubMed: 7738033]

[10]. Robledo O, Guillet C, Chevalier S, et al. Hepatocyte-derived cell lines express a functional receptor for cardiotrophin-1. Eur Cytokine Netw. 1997; 8(3):245-52. [PubMed: 9346356]

[11]. Gearing DP, Comeau MR, Friend DJ, et al. The IL-6 signal transducer, gp130: an oncostatin M receptor and affinity converter for the LIF receptor. Science. 1992; 255(5050):1434-7. [PubMed: 1542794]

[12]. Ichihara M, Hara T, Kim H, Murate T, Miyajima A. Oncostatin M and leukemia inhibitory factor do not use the same functional receptor in mice. Blood. 1997; 90(1):165-73. [PubMed: 9207450]

[13]. Davis S, Aldrich TH, Stahl N, et al. LIFR beta and gp130 as heterodimerizing signal transducers of the tripartite CNTF receptor. Science. 1993; 260(5115):1805-8. [PubMed: 8390097]

[14]. Elson GC, Lelievre E, Guillet C, et al. CLF associates with CLC to form a functional heteromeric ligand for the CNTF receptor complex. Nat Neurosci. 2000; 3(9):867-72. [PubMed: 10966616] 
[15]. Derouet D, Rousseau F, Alfonsi F, et al. Neuropoietin, a new IL-6-related cytokine signaling through the ciliary neurotrophic factor receptor. Proc Natl Acad Sci USA. 2004; 101(14):482732. [PubMed: 15051883]

[16]. White UA, Stephens JM. Neuropoietin activates STAT3 independent of LIFR activation in adipocytes. Biochem Biophys Res Commun. 2010

[17]. Balhoff JP, Stephens JM. Highly specific and quantitative activation of STATs in 3T3-L1 adipocytes. Biochem Biophys Res Commun. 1998; 247(3):894-900. [PubMed: 9647789]

[18]. Tenney R, Stansfield K, Pekala PH. Interleukin 11 signaling in 3T3-L1 adipocytes. J Cell Physiol. 2005; 202(1):160-6. [PubMed: 15389536]

[19]. Stephens JM, Lumpkin SJ, Fishman JB. Activation of signal transducers and activators of transcription 1 and 3 by leukemia inhibitory factor, oncostatin-M, and interferon-gamma in adipocytes. J Biol Chem. 1998; 273(47):31408-16. [PubMed: 9813052]

[20]. Rotter V, Nagaev I, Smith U. Interleukin-6 (IL-6) induces insulin resistance in 3T3-L1 adipocytes and is, like IL-8 and tumor necrosis factor-alpha, overexpressed in human fat cells from insulin-resistant subjects. J Biol Chem. 2003; 278(46):45777-84. [PubMed: 12952969]

[21]. Lagathu C, Bastard JP, Auclair M, Maachi M, Capeau J, Caron M. Chronic interleukin-6 (IL-6) treatment increased IL-6 secretion and induced insulin resistance in adipocyte: prevention by rosiglita-zone. Biochem Biophys Res Commun. 2003; 311(2):372-9. [PubMed: 14592424]

[22]. Zvonic S, Cornelius P, Stewart WC, Mynatt RL, Stephens JM. The regulation and activation of ciliary neurotrophic factor signaling proteins in adipocytes. J Biol Chem. 2003; 278(4):2228-35. [PubMed: 12424252]

[23]. Zvonic S, Hogan JC, Arbour-Reily P, Mynatt RL, Stephens JM. Effects of cardiotrophin on adipocytes. J Biol Chem. 2004; 279(46):47572-9. [PubMed: 15339920]

[24]. White UA, Stewart WC, Mynatt RL, Stephens JM. Neuropoietin attenuates adipogenesis and induces insulin resistance in adipocytes. J Biol Chem. 2008; 283(33):22505-12. [PubMed: 18562323]

[25]. Miyaoka Y, Tanaka M, Naiki T, Miyajima A. Oncostatin M inhibits adipogenesis through the RAS/ERK and STAT5 signaling pathways. J Biol Chem. 2006; 281(49):37913-20. [PubMed: 17028188]

[26]. Song HY, Jeon ES, Kim JI, Jung JS, Kim JH. Oncostatin M promotes osteogenesis and suppresses adipogenic differentiation of human adipose tissue-derived mesenchymal stem cells. J Cell Biochem. 2007; 101(5):1238-51. [PubMed: 17226768]

[27]. Hogan JC, Stephens JM. Effects of leukemia inhibitory factor on 3T3-L1 adipocytes. J Endocrinol. 2005; 185(3):485-96. [PubMed: 15930175]

[28]. Meng L, Zhou J, Sasano H, Suzuki T, Zeitoun KM, Bulun SE. Tumor necrosis factor alpha and interleukin 11 secreted by malignant breast epithelial cells inhibit adipocyte differentiation by selectively down-regulating CCAAT/enhancer binding protein alpha and peroxisome proliferator-activated receptor gamma: mechanism of desmoplastic reaction. Cancer Res. 2001; 61(5):2250-5. [PubMed: 11280794]

[29]. Keller DC, Du XX, Srour EF, Hoffman R, Williams DA. Interleukin-11 inhibits adipogenesis and stimulates myelopoiesis in human long-term marrow cultures. Blood. 1993; 82(5):1428-35. [PubMed: 7689869]

[30]. Sopasakis VR, Sandqvist M, Gustafson B, et al. High local concentrations and effects on differentiation implicate interleukin-6 as a paracrine regulator. Obes Res. 2004; 12(3):454-60. [PubMed: 15044662]

[31]. Eder K, Baffy N, Falus A, Fulop AK. The major inflammatory mediator interleukin-6 and obesity. Inflamm Res. 2009; 58(11):727-36. [PubMed: 19543691]

[32]. Mohamed-Ali V, Goodrick S, Rawesh A, et al. Subcutaneous adipose tissue releases interleukin-6, but not tumor necrosis factor-alpha, in vivo. J Clin Endocrinol Metab. 1997; 82(12):4196-200. [PubMed: 9398739]

[33]. Fried SK, Bunkin DA, Greenberg AS. Omental and subcutaneous adipose tissues of obese subjects release interleukin-6: depot difference and regulation by glucocorticoid. J Clin Endocrinol Metab. 1998; 83(3):847-50. [PubMed: 9506738] 
[34]. Weisberg SP, McCann D, Desai M, Rosenbaum M, Leibel RL, Ferrante AW Jr. Obesity is associated with macrophage accumulation in adipose tissue. J Clin Invest. 2003; 112(12):1796808. [PubMed: 14679176]

[35]. Fain JN, Madan AK, Hiler ML, Cheema P, Bahouth SW. Comparison of the release of adipokines by adipose tissue, adipose tissue matrix, and adipocytes from visceral and subcutaneous abdominal adipose tissues of obese humans. Endocrinology. 2004; 145(5):227382. [PubMed: 14726444]

[36]. Mooney RA. Counterpoint: Interleukin-6 does not have a beneficial role in insulin sensitivity and glucose homeostasis. J Appl Physiol. 2007; 102(2):816-8. [PubMed: 17284655]

[37]. Pedersen BK, Febbraio MA. Point: Interleukin-6 does have a beneficial role in insulin sensitivity and glucose homeostasis. J Appl Physiol. 2007; 102(2):814-6. [PubMed: 17068210]

[38]. Kristiansen OP, Mandrup-Poulsen T. Interleukin-6 and diabetes: the good, the bad, or the indifferent? Diabetes. 2005; 54(Suppl 2):S114-24. [PubMed: 16306329]

[39]. Gnacinska M, Malgorzewicz S, Guzek M, Lysiak-Szydlowska W, Sworczak K. Adipose tissue activity in relation to overweight or obesity. Endokrynol Pol. 2010; 61(2):160-8. [PubMed: 20464701]

[40]. Khaodhiar L, Ling PR, Blackburn GL, Bistrian BR. Serum levels of interleukin-6 and C-reactive protein correlate with body mass index across the broad range of obesity. JPEN J Parenter Enteral Nutr. 2004; 28(6):410-5. [PubMed: 15568287]

[41]. Roytblat L, Rachinsky M, Fisher A, et al. Raised interleukin-6 levels in obese patients. Obes Res. 2000; 8(9):673-5. [PubMed: 11225716]

[42]. Bastard JP, Jardel C, Bruckert E, et al. Elevated levels of interleukin 6 are reduced in serum and subcutaneous adipose tissue of obese women after weight loss. J Clin Endocrinol Metab. 2000; 85(9):3338-42. [PubMed: 10999830]

[43]. Pou KM, Massaro JM, Hoffmann U, et al. Visceral and subcutaneous adipose tissue volumes are cross-sectionally related to markers of inflammation and oxidative stress: the Framingham Heart Study. Circulation. 2007; 116(11):1234-41. [PubMed: 17709633]

[44]. Fontana L, Eagon JC, Trujillo ME, Scherer PE, Klein S. Visceral fat adipokine secretion is associated with systemic inflammation in obese humans. Diabetes. 2007; 56(4):1010-13. [PubMed: 17287468]

[45]. Wallenius V, Wallenius K, Ahren B, et al. Interleukin-6-deficient mice develop mature-onset obesity. Nat Med. 2002; 8(1):75-9. [PubMed: 11786910]

[46]. Di Gregorio GB, Hensley L, Lu T, Ranganathan G, Kern PA. Lipid and carbohydrate metabolism in mice with a targeted mutation in the IL-6 gene: absence of development of age-related obesity. Am J Physiol Endocrinol Metab. 2004; 287(1):E182-7. [PubMed: 15191885]

[47]. Hansen D, Dendale P, Beelen M, et al. Plasma adipokine and inflammatory marker concentrations are altered in obese, as opposed to non-obese, type 2 diabetes patients. Eur J Appl Physiol. 2010

[48]. Kern PA, Ranganathan S, Li C, Wood L, Ranganathan G. Adipose tissue tumor necrosis factor and interleukin-6 expression in human obesity and insulin resistance. Am J Physiol Endocrinol Metab. 2001; 280(5):E745-51. [PubMed: 11287357]

[49]. Vozarova B, Weyer C, Hanson K, Tataranni PA, Bogardus C, Pratley RE. Circulating interleukin-6 in relation to adiposity, insulin action, and insulin secretion. Obes Res. 2001; 9(7): 414-7. [PubMed: 11445664]

[50]. Carey AL, Bruce CR, Sacchetti M, et al. Interleukin-6 and tumor necrosis factor-alpha are not increased in patients with Type 2 diabetes: evidence that plasma interleukin- 6 is related to fat mass and not insulin responsiveness. Diabetologia. 2004; 47(6):1029-37. [PubMed: 15168015]

[51]. Klover PJ, Zimmers TA, Koniaris LG, Mooney RA. Chronic exposure to interleukin-6 causes hepatic insulin resistance in mice. Diabetes. 2003; 52(11):2784-9. [PubMed: 14578297]

[52]. Klover PJ, Clementi AH, Mooney RA. Interleukin-6 depletion selectively improves hepatic insulin action in obesity. Endocrinology. 2005; 146(8):3417-27. [PubMed: 15845623]

[53]. Senn JJ, Klover PJ, Nowak IA, Mooney RA. Interleukin-6 induces cellular insulin resistance in hepatocytes. Diabetes. 2002; 51(12):3391-9. [PubMed: 12453891] 
[54]. Senn JJ, Klover PJ, Nowak IA, et al. Suppressor of cytokine signaling-3 (SOCS-3), a potential mediator of interleukin-6-dependent insulin resistance in hepatocytes. J Biol Chem. 2003; 278(16):13740-6. [PubMed: 12560330]

[55]. Kim HJ, Higashimori T, Park SY, et al. Differential effects of interleukin-6 and -10 on skeletal muscle and liver insulin action in vivo. Diabetes. 2004; 53(4):1060-7. [PubMed: 15047622]

[56]. Kanemaki T, Kitade H, Kaibori M, et al. Interleukin 1beta and interleukin 6, but not tumor necrosis factor alpha, inhibit insulin-stimulated glycogen synthesis in rat hepatocytes. Hepatology. 1998; 27(5):1296-303. [PubMed: 9581683]

[57]. Hiscock N, Chan MH, Bisucci T, Darby IA, Febbraio MA. Skeletal myocytes are a source of interleukin-6 mRNA expression and protein release during contraction: evidence of fiber type specificity. FASEB J. 2004; 18(9):992-4. [PubMed: 15059966]

[58]. Steensberg A, Febbraio MA, Osada T, et al. Interleukin-6 production in contracting human skeletal muscle is influenced by pre-exercise muscle glycogen content. J Physiol. 2001; 537(Pt 2):633-9. [PubMed: 11731593]

[59]. Steensberg A, van HG, Osada T, Sacchetti M, Saltin B, Klarlund PB. Production of interleukin-6 in contracting human skeletal muscles can account for the exercise-induced increase in plasma inter-leukin-6. J Physiol. 2000; 529(Pt 1):237-42. [PubMed: 11080265]

[60]. King DS, Dalsky GP, Clutter WE, et al. Effects of exercise and lack of exercise on insulin sensitivity and responsiveness. J Appl Physiol. 1988; 64(5):1942-6. [PubMed: 3292505]

[61]. Wojtaszewski JF, Hansen BF, Gade, et al. Insulin signaling and insulin sensitivity after exercise in human skeletal muscle. Diabetes. 2000; 49(3):325-31. [PubMed: 10868952]

[62]. Spranger J, Kroke A, Mohlig M, et al. Inflammatory cytokines and the risk to develop type 2 diabetes: results of the prospective population-based European Prospective Investigation into Cancer and Nutrition (EPIC)-Potsdam Study. Diabetes. 2003; 52(3):812-7. [PubMed: 12606524]

[63]. Hu FB, Meigs JB, Li TY, Rifai N, Manson JE. Inflammatory markers and risk of developing type 2 diabetes in women. Diabetes. 2004; 53(3):693-700. [PubMed: 14988254]

[64]. Pradhan AD, Manson JE, Rifai N, Buring JE, Ridker PM. C-reactive protein, interleukin 6, and risk of developing type 2 diabetes mellitus. JAMA. 2001; 286(3):327-34. [PubMed: 11466099]

[65]. Petersen EW, Carey AL, Sacchetti M, et al. Acute IL-6 treatment increases fatty acid turnover in elderly humans in vivo and in tissue culture in vitro. Am J Physiol Endocrinol Metab. 2005; 288(1):E155-62. [PubMed: 15383370]

[66]. van HG, Steensberg A, Sacchetti M, et al. Interleukin-6 stimulates lipolysis and fat oxidation in humans. J Clin Endocrinol Metab. 2003; 88(7):3005-10. [PubMed: 12843134]

[67]. Lyngso D, Simonsen L, Bulow J. Metabolic effects of interleukin-6 in human splanchnic and adipose tissue. J Physiol. 2002; 543(Pt 1):379-86. [PubMed: 12181308]

[68]. Greenberg AS, Nordan RP, McIntosh J, Calvo JC, Scow RO, Jablons D. Interleukin 6 reduces lipoprotein lipase activity in adipose tissue of mice in vivo and in 3T3-L1 adipocytes: a possible role for interleukin 6 in cancer cachexia. Cancer Res. 1992; 52(15):4113-6. [PubMed: 1638523]

[69]. Yang Y, Ju D, Zhang M, Yang G. Interleukin-6 stimulates lipolysis in porcine adipocytes. Endocrine. 2008; 33(3):261-9. [PubMed: 19016005]

[70]. Trujillo ME, Sullivan S, Harten I, Schneider SH, Greenberg AS, Fried SK. Interleukin-6 regulates human adipose tissue lipid metabolism and leptin production in vitro. J Clin Endocrinol Metab. 2004; 89(11):5577-82. [PubMed: 15531514]

[71]. Bruun JM, Lihn AS, Verdich C, et al. Regulation of adiponectin by adipose tissue-derived cytokines: in vivo and in vitro investigations in humans. Am J Physiol Endocrinol Metab. 2003; 285(3):E527-33. [PubMed: 12736161]

[72]. Simons PJ, van den Pangaart PS, Aerts JM, Boon L. Pro-inflammatory delipidizing cytokines reduce adiponectin secretion from human adipocytes without affecting adiponectin oligomerization. J Endocrinol. 2007; 192(2):289-99. [PubMed: 17283229]

[73]. Sleeman MW, Anderson KD, Lambert PD, Yancopoulos GD, Wiegand SJ. The ciliary neurotrophic factor and its receptor, CNTFR alpha. Pharm Acta Helv. 2000; 74(2-3):265-72. [PubMed: 10812968] 
[74]. Miller RG, Petajan JH, Bryan WW, et al. A placebo-controlled trial of recombinant human ciliary neurotrophic (rhCNTF) factor in amyotrophic lateral sclerosis. rhCNTF ALS Study Group. Ann Neurol. 1996; 39(2):256-60. [PubMed: 8967757]

[75]. Gloaguen I, Costa P, Demartis A, et al. Ciliary neurotrophic factor corrects obesity and diabetes associated with leptin deficiency and resistance. Proc Natl Acad Sci USA. 1997; 94(12):645661. [PubMed: 9177239]

[76]. Lambert PD, Anderson KD, Sleeman MW, et al. Ciliary neurotrophic factor activates leptin-like pathways and reduces body fat, without cachexia or rebound weight gain, even in leptin-resistant obesity. Proc Natl Acad Sci USA. 2001; 98(8):4652-7. [PubMed: 11259650]

[77]. Sleeman MW, Garcia K, Liu R, et al. Ciliary neurotrophic factor improves diabetic parameters and hepatic steatosis and increases basal metabolic rate in $\mathrm{db} / \mathrm{db}$ mice. Proc Natl Acad Sci USA. 2003; 100(24):14297-302. [PubMed: 14610276]

[78]. Ettinger MP, Littlejohn TW, Schwartz SL, et al. Recombinant variant of ciliary neurotrophic factor for weight loss in obese adults: a randomized, dose-ranging study. JAMA. 2003; 289(14): 1826-32. [PubMed: 12684362]

[79]. Bluher S, Moschos S, Bullen J Jr. et al. Ciliary neurotrophic factorAx15 alters energy homeostasis, decreases body weight, and improves metabolic control in diet-induced obese and UCP1-DTA mice. Diabetes. 2004; 53(11):2787-96. [PubMed: 15504958]

[80]. Liu QS, Gao M, Zhu SY, et al. The novel mechanism of recombinant human ciliary neurotrophic factor on the anti-diabetes activity. Basic Clin Pharmacol Toxicol. 2007; 101(2):78-84. [PubMed: 17651306]

[81]. Ott V, Fasshauer M, Dalski A, Klein HH, Klein J. Direct effects of ciliary neurotrophic factor on brown adipocytes: evidence for a role in peripheral regulation of energy homeostasis. J Endocrinol. 2002; 173(2):R1-8. [PubMed: 12010646]

[82]. Watt MJ, Dzamko N, Thomas WG, et al. CNTF reverses obesity-induced insulin resistance by activating skeletal muscle AMPK. Nat Med. 2006; 12(5):541-8. [PubMed: 16604088]

[83]. Crowe S, Turpin SM, Ke F, Kemp BE, Watt MJ. Metabolic remodeling in adipocytes promotes ciliary neurotrophic factor-mediated fat loss in obesity. Endocrinology. 2008; 149(5):2546-56. [PubMed: 18276754]

[84]. Duff E, Li CL, Hartzell DL, Choi YH, la-Fera MA, Baile CA. Ciliary neurotrophic factor injected icv induces adipose tissue apoptosis in rats. Apoptosis. 2004; 9(5):629-34. [PubMed: 15314291]

[85]. Ott V, Fasshauer M, Meier B, et al. Ciliary neurotrophic factor influences endocrine adipocyte function: inhibition of leptin via PI 3-kinase. Mol Cell Endocrinol. 2004; 224(1-2):21-7. [PubMed: 15353177]

[86]. Williams RL, Hilton DJ, Pease S, et al. Myeloid leukaemia inhibitory factor maintains the developmental potential of embryonic stem cells. Nature. 1988; 336(6200):684-7. [PubMed: 3143916]

[87]. Mori M, Yamaguchi K, Abe K. Purification of a lipoprotein lipase-inhibiting protein produced by a melanoma cell line associated with cancer cachexia. Biochem Biophys Res Commun. 1989; 160(3):1085-92. [PubMed: 2730639]

[88]. Marshall MK, Doerrler W, Feingold KR, Grunfeld C. Leukemia inhibitory factor induces changes in lipid metabolism in cultured adipocytes. Endocrinology. 1994; 135(1):141-7. [PubMed: 8013346]

[89]. Aubert J, Dessolin S, Belmonte N, et al. Leukemia inhibitory factor and its receptor promote adipocyte differentiation via the mitogen-activated protein kinase cascade. J Biol Chem. 1999; 274(35):24965-72. [PubMed: 10455174]

[90]. Gimble JM, Wanker F, Wang CS, et al. Regulation of bone marrow stromal cell differentiation by cytokines whose receptors share the gp130 protein. J Cell Biochem. 1994; 54(1):122-33. [PubMed: 8126083]

[91]. Zarling JM, Shoyab M, Marquardt H, Hanson MB, Lioubin MN, Todaro GJ. Oncostatin M: a growth regulator produced by differentiated histiocytic lymphoma cells. Proc Natl Acad Sci USA. 1986; 83(24):9739-43. [PubMed: 3540948] 
[92]. Rose TM, Lagrou MJ, Fransson I, et al. The genes for oncostatin M (OSM) and leukemia inhibitory factor (LIF) are tightly linked on human chromosome 22. Genomics. 1993; 17(1):13640. [PubMed: 8406444]

[93]. Rose TM, Bruce AG. Oncostatin M is a member of a cytokine family that includes leukemiainhibitory factor, granulocyte colony-stimulating factor, and interleukin 6. Proc Natl Acad Sci USA. 1991; 88(19):8641-5. [PubMed: 1717982]

[94]. Mosley B, De IC, Friend D, et al. Dual oncostatin M (OSM) receptors. Cloning and characterization of an alternative signaling subunit conferring OSM-specific receptor activation. J Biol Chem. 1996; 271(51):32635-43. [PubMed: 8999038]

[95]. Song HY, Kim MR, Lee MJ, et al. Oncostatin M decreases adiponectin expression and induces dedifferentiation of adipocytes by JAK3- and MEK-dependent pathways. Int J Biochem Cell Biol. 2007; 39(2):439-49. [PubMed: 17081797]

[96]. Pennica D, King KL, Shaw KJ, et al. Expression cloning of cardiotrophin 1, a cytokine that induces cardiac myocyte hypertrophy. Proc Natl Acad Sci USA. 1995; 92(4):1142-6. [PubMed: 7862649]

[97]. Wollert KC, Taga T, Saito M, et al. Cardiotrophin-1 activates a distinct form of cardiac muscle cell hypertrophy. Assembly of sarcomeric units in series VIA gp130/leukemia inhibitory factor receptor-dependent pathways. J Biol Chem. 1996; 271(16):9535-45. [PubMed: 8621626]

[98]. Calabro P, Limongelli G, Riegler L, et al. Novel insights into the role of cardiotrophin-1 in cardiovascular diseases. J Mol Cell Cardiol. 2009; 46(2):142-8. [PubMed: 19059413]

[99]. Pemberton CJ, Raudsepp SD, Yandle TG, Cameron VA, Richards AM. Plasma cardiotrophin-1 is elevated in human hypertension and stimulated by ventricular stretch. Cardiovasc Res. 2005; 68(1):109-17. [PubMed: 15978561]

[100]. Talwar S, Squire IB, O'brien RJ, Downie PF, Davies JE, Ng LL. Plasma cardiotrophin-1 following acute myocardial infarction: relationship with left ventricular systolic dysfunction. Clin Sci (Lond). 2002; 102(1):9-14. [PubMed: 11749655]

[101]. Tsutamoto T, Wada A, Maeda K, et al. Relationship between plasma level of cardiotrophin-1 and left ventricular mass index in patients with dilated cardiomyopathy. J Am Coll Cardiol. 2001; 38(5):1485-90. [PubMed: 11691527]

[102]. Zvonic S, Baugh JE Jr. Arbour-Reily P, Mynatt RL, Stephens JM. Cross-talk among gp130 cytokines in adipocytes. J Biol Chem. 2005; 280(40):33856-63. [PubMed: 16096272]

[103]. Natal C, Fortuno MA, Restituto P, et al. Cardiotrophin-1 is expressed in adipose tissue and upregulated in the metabolic syndrome. Am J Physiol Endocrinol Metab. 2008; 294(1):E52-60. [PubMed: 17940213]

[104]. Ohno M, Kohyama J, Namihira M, et al. Neuropoietin induces neuroepithelial cells to differentiate into astrocytes via activation of STAT3. Cytokine. 2006; 36(1-2):17-22. [PubMed: 17161614]

[105]. Paul SR, Bennett F, Calvetti JA, et al. Molecular cloning of a cDNA encoding interleukin 11, a stromal cell-derived lymphopoietic and hematopoietic cytokine. Proc Natl Acad Sci USA. 1990; 87(19):7512-6. [PubMed: 2145578]

[106]. Ohsumi J, Miyadai K, Kawashima I, et al. Adipogenesis inhibitory factor. A novel inhibitory regulator of adipose conversion in bone marrow. FEBS Lett. 1991; 288(1-2):13-6. [PubMed: 1831770]

[107]. Kawashima I, Ohsumi J, Mita-Honjo K, et al. Molecular cloning of cDNA encoding adipogenesis inhibitory factor and identity with interleukin-11. FEBS Lett. 1991; 283(2):199202. [PubMed: 1828438]

[108]. Okazaki R, Toriumi M, Fukumoto S, et al. Thiazolidinediones inhibit osteoclast-like cell formation and bone resorption in vitro. Endocrinology. 1999; 140(11):5060-5. [PubMed: 10537132]

[109]. Garcia P,V, Morita I, Murota S. Expression of adipogenesis markers in a murine stromal cell line treated with 15-deoxy Delta(12,14)-prostaglandin J2, interleukin-11, 9-cis retinoic acid and vitamin K2. Prostaglandins Leukot Essent Fatty Acids. 2001; 65(4):215-21. [PubMed: $11728175]$ 
[110]. Yin T, Yang YC. Mitogen-activated protein kinases and ribosomal S6 protein kinases are involved in signaling pathways shared by interleukin-11, interleukin-6, leukemia inhibitory factor, and oncostatin M in mouse 3T3-L1 cells. J Biol Chem. 1994; 269(5):3731-8. [PubMed: 7508917]

[111]. Fuhrer DK, Yang YC. Activation of Src-family protein tyrosine kinases and phosphatidylinositol 3-kinase in 3T3-L1 mouse preadipocytes by interleukin-11. Exp Hematol. 1996; 24(2):195-203. [PubMed: 8641341]

[112]. Lgssiar A, Hassan M, Schott-Ohly P, et al. Interleukin-11 inhibits NF-kappaB and AP-1 activation in islets and prevents diabetes induced with streptozotocin in mice. Exp Biol Med (Maywood ). 2004; 229(5):425-36. [PubMed: 15096655]

[113]. Senaldi G, Varnum BC, Sarmiento U, et al. Novel neurotrophin-1/B cell-stimulating factor-3: a cytokine of the IL-6 family. Proc Natl Acad Sci USA. 1999; 96(20):11458-63. [PubMed: 10500198]

[114]. Shi Y, Wang W, Yourey PA, et al. Computational EST database analysis identifies a novel member of the neuropoietic cytokine family. Biochem Biophys Res Commun. 1999; 262(1):1328. [PubMed: 10448081]

[115]. Vlotides G, Zitzmann K, Stalla GK, Auernhammer CJ. Novel neurotrophin-1/B cell-stimulating factor-3 (NNT-1/BSF-3)/cardiotrophin-like cytokine (CLC)--a novel gp130 cytokine with pleiotropic functions. Cytokine Growth Factor Rev. 2004; 15(5):325-36. [PubMed: 15450249]

[116]. Villarino AV, Huang E, Hunter CA. Understanding the pro- and anti-inflammatory properties of IL-27. J Immunol. 2004; 173(2):715-20. [PubMed: 15240655]

[117]. Lopez B, Gonzalez A, Querejeta R, Barba J, Diez J. Association of plasma cardiotrophin-1 with stage $\mathrm{C}$ heart failure in hypertensive patients: potential diagnostic implications. J Hypertens. 2009; 27(2):418-24. [PubMed: 19155793]

[118]. Malavazos AE, Ermetici F, Morricone L, et al. Association of increased plasma cardiotrophin-1 with left ventricular mass indexes in normotensive morbid obesity. Hypertension. 2008; 51(2):e8-e9. [PubMed: 18180396]

[119]. Hirota H, Izumi M, Hamaguchi T, et al. Circulating interleukin-6 family cytokines and their receptors in patients with congestive heart failure. Heart Vessels. 2004; 19(5):237-41. [PubMed: 15372299]

[120]. Naemura JR, Radka SF. Detection of oncostatin M in human plasma and serum by a sensitive enzyme immunoassay. Lymphokine Cytokine Res. 1993; 12(3):187-90. [PubMed: 8347766]

[121]. Heizmann O, Koeller M, Muhr G, Oertli D, Schinkel C. Th1- and Th2-type cytokines in plasma after major trauma. J Trauma. 2008; 65(6):1374-8. [PubMed: 19077629]

[122]. Miyagaki T, Sugaya M, Shibata S, Ohmatsu H, Fujita H, Tamaki K. Serum interleukin-27 levels in patients with cutaneous T-cell lymphoma. Clin Exp Dermatol. 2009 


\begin{tabular}{|c|c|c|c|c|c|c|c|}
\hline & & & & & $\hat{z}$ & -. $\frac{\infty}{\frac{m}{50}}$ & 莺 \\
\hline & U్త & 永 & 兽 & & $\begin{array}{l}\sum_{0} \\
0\end{array}$ & $\begin{array}{ll}\sum_{0}^{\infty} & 0 \\
\frac{\pi}{0}\end{array}$ & \\
\hline & $\bar{z}$ & 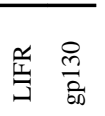 & 若 & & 今 & $\begin{array}{ll}\bar{x} & 0 \\
0 & 0 \\
\vdots & 0 \\
\end{array}$ & \\
\hline & 志 & 总 & & & $\overline{\vec{b}}$ & 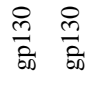 & $\begin{array}{l}\stackrel{8}{\Xi} \\
\stackrel{\Xi}{=}\end{array}$ \\
\hline$\stackrel{900}{.9}$ & İ & 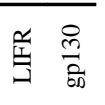 & & 望 & 总 & 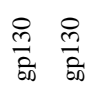 & $\begin{array}{l}\stackrel{2}{6} \\
\stackrel{1}{日} \\
=\end{array}$ \\
\hline 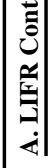 & 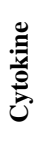 & 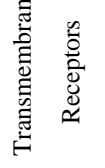 & 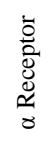 & | & 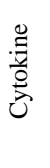 & 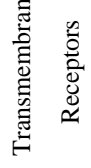 & 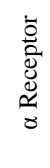 \\
\hline
\end{tabular}

Curr Pharm Des. Author manuscript; available in PMC 2011 June 22. 
Table 2

The Effect of gp130 Cytokines on Adipocyte Differentiation

\begin{tabular}{|c|c|c|}
\hline gp 130 Cytokine & Effect on Adipogenesis & Reference(s) \\
\hline CNTF & No effect & {$[22]$} \\
\hline CT-1 & No effect & {$[23]$} \\
\hline IL-11 & Inhibitory & {$[28,29,106,107]$} \\
\hline LIF & Controversial & $\begin{array}{c}\text { Pro-adipogenic } 89 \\
\text { No effect 24, 27 } \\
\text { Anti-adipogenic 90 }\end{array}$ \\
\hline NP & Inhibitory & {$[24]$} \\
\hline OSM & Inhibitory & {$[24,25]$} \\
\hline
\end{tabular}


Table 3

The Effect of gp130 Cytokines on Insulin Sensitivity in Adipocytes.

\begin{tabular}{|c|c|c|}
\hline gp 130 Cytokine & Effect on Insulin Action & Reference(s) \\
\hline CNTF & Insulin sensitizer & {$[22,75,77]$} \\
\hline CT-1 & Induce insulin resistance & {$[23]$} \\
\hline IL-6 & Controversial & {$[20,21,45-61]$} \\
\hline LIF & No effect & {$[27]$} \\
\hline NP & Induce insulin resistance & {$[24]$} \\
\hline
\end{tabular}

